\title{
The Effect of Audit Going Concern on the Prediction Model of Bankruptcy and Reputation Auditor
}

\author{
Hanny Oktaria \\ Politeknik Negeri Batam \\ Batam, Indonesia
}

\begin{abstract}
The purpose of this study is to determine the relationship of issuing going concern audit opinion by the Public Accounting Firm (KAP) against the predicted model of bankruptcy of manufacturing companies in Indonesia. The next goal is to find out how much influence will be generated on the reputation of the auditor if the Public Accounting Firm (KAP) issued a going concern audit opinion. This research is conducted to analyze whether there is influence on issuing going concern audit opinion by Public Accounting Firm (KAP) based on bankruptcy prediction model and auditor reputation at manufacturing company in Indonesia. This research performs sample test in the period of study year 2013-2015 by testing the data through SPSS version 17 . The results showed that the predicted model of bankruptcy used to influence the acceptance of going concern audit opinion on the related companies. The auditor's reputation variable has no effect on the acceptance of going concern audit opinion.
\end{abstract}

\section{Keywords-Bankruptcy, reputation auditor, KAP, spss}

\section{INTRODUCTION}

The external audit mechanism should be in accordance with the regulations issued by the Indonesian government. Any process undertaken by the Public Accounting Firm (KAP) will be directly related to the condition of the company during the audit process. Audit results issued by the Public Accounting Firm (KAP) related will affect the sustainability of the company being audited.

Survival of the company's survival is an indication of bankruptcy. Altman found that the predicted rate of bankruptcy using a prediction model reached the level of $82 \%$ accuracy and suggested the use of bankruptcy prediction model as an auditor tool to decide the company's ability to maintain its survival [1].

The audit report with the modification of going concern is an indication that in the auditor's assessment there is a risk the company cannot survive in business [2]. The issue of going concern should be given by the auditor and incorporated into the audit opinion when the audit opinion is published. The auditor is responsible for evaluating whether there is great doubt about the entity's ability to maintain its viability within a reasonable period of time.

The reputation of a Public Accounting Firm (KAP) is at stake when the opinion given does not match the actual condition of the company. The auditor must have the courage to disclose issues concerning the going concern of the client company. Subekti pointed out that the International Public Accounting Firm (KAP) or better known in Indonesia as the big four is considered to perform audits more efficiently and has a big responsibility for issuing going concern audit opinion on the company being audited [3].

\section{HYPOTHESIS}

H1: Influence of Bankruptcy Prediction Model to Acceptance of Audit Going Concern Opinion.

The prediction model of bankruptcy related to the issue of going concern audit opinion on the basis of the theory of business continuity is the variable to be assessed in this study. The variables will be tested by looking at how the effect on a binding basis. Where the independent auditor issued an opinion then will be evaluated by the management company. The management will provide an assessment of the audit process conducted so that it will affect the position of the independent audit. Unqualified audit opinion with explanatory paragraphs is closely related to a going concern audit opinion which states that financial statements present fairly, in all material respects, financial position, results of operations and cash flows of certain entities in accordance with generally accepted accounting principles in Indonesia

H2: The Influence of the Auditor's Reputation of the Acceptance of Audit Going Concern.

A reputable and reputable auditor can provide better audit quality, including in the matter of going concern. The better the reputation of a Public Accounting Firm (KAP), then the accountant is likely to give an opinion about the going concern of a company. The auditor's reputation also shows the public's achievements and beliefs that the auditor holds on behalf of the auditor.

Creswell et al., in Fanny and Saputra states that clients usually perceive that auditors from large Public Accounting Firm (KAP) and have affiliation with the International Public Accounting Firm (KAP) have higher quality audit results because the auditor has characteristics that can be related to quality, such as training, international recognition, and the existence of peer review [4]. There is a tendency to change the auditor if the Public Accounting Firm (KAP) is not competent in conducting the audit process. Public Accounting Firm (KAP) included in the big four will also influence management decisions within the turn of the independent audit as an 
external audit company. Based on the existing theoretical basis, it can be arranged hypothesis as follows.

\section{RESEARCH VARIABLES AND OPERATIONAL DEFINITION}

Dependent variable in this research is going concern audit opinion. The opinion is an audit opinion with an explanatory paragraph on the auditor's consideration that there is a significant incapability or uncertainty about the company's viability in carrying out its operations in the future. The process of data processing is done by classifying going-concern audit opinion into two groups, if given a going concern audit opinion it will be given code 1 and if not given going-concern audit opinion it will be given code 0 . This is done because this study uses dummy data.

\section{A. Independent Variables}

The first independent variable in this study is the prediction model of bankruptcy. If the auditor issues a going concern audit opinion, then the company tends to make auditor changes based on several aspects of consideration. This phenomenon is also known as the prediction model of bankruptcy $\left(Z^{\prime}\right)$. The predicted bankruptcy prediction model known as $\mathrm{Z}$ score (Altman) is determined using the following formula proposed by Munawir to detect corporate bankruptcy in several periods prior to the occurrence of bankruptcy [5]. The formula is:

$$
Z^{\prime}=1,2 X 1+1,4 X 2+3,3 X 3+0,6 X 4+1,0 X 5
$$

\section{Information:}

$\mathrm{X} 1$ = working capital / total assets

$\mathrm{X} 2=$ retained earnings / total assets

$\mathrm{X} 3$ = earnings before cost and tax / total assets

$\mathrm{X} 4$ = stock market price / book value total debt

$\mathrm{X} 5=$ sales $/$ total assets

\section{B. The Second Independent Variable in This Study is the Auditor's Reputation (AR).}

The reputation of the auditor (AR) in this study is proxied by the size of Public Accounting Firm (KAP) using dummy variables. If the Public Accounting Firm (KAP) is included in the category of the big four auditors it will be given a code 1, whereas if not included into the category of the big four auditors it will be given a code 0. The Public Accounting Firm (KAP) big four in Indonesia are:

- Pricewaterhouse Coopers with its partner in Indonesia is Haryanto Sahari and Rekan.

- Deloitte Touche Tohmatsu with his partner in Indonesia is Osman Bing Satrio and Rekan.

- KPMG International with its partner in Indonesia is Siddharta and Widjaja.

- Ernst and Young with his partner in Indonesia namely Purwantono, Sarwoko, and Sandjaja.

1) Technique of sample number determination: The population of this study are all manufacturing companies listed on the Indonesia Stock Exchange (IDX) during the period 2013-2015. The process of selecting the sample using purposive sampling method. The method of purposive sampling is the determination of the sample based on the criteria that have been formulated in advance by researchers [6]. The criteria of the companies sampled in this study are as follows:

- Listed on the Indonesia Stock Exchange (IDX) during the study period (2013-2015)

- Have a negative net profit of at least two periods of financial statements during the period of observation (2013-2015). Negative net income is used to indicate the company's troubled financial condition and has a tendency to accept going concern audit opinion.

- The required data is available in full and publishes financial statements audited by independent auditors from 2013-2015.

Using the period of financial statements from January 1 to 31 December and or rupiah as the reporting currency.

\section{DATA PROCESSING TECHNIQUe}

Data processing used in this research is by using SPSS version 17. This research uses three steps in managing data that have been obtained from respondent. The first stage begins with editing; the purpose is to examine whether the company's financial report to be examined is good enough as an effort to maintain the quality of data in order to be processed further. The second stage is the coding of the research variables. The third stage is tabulating (tabulating), where the data have been obtained arranged in the form of frequency distribution table.

\section{DATA ANALYSIS TEChNiQUe}

Hypothesis testing of the research was done by using simple linear regression analysis in SPSS 17 program. Before the regression analysis, the data must meet the requirements of classical assumption test. Descriptive Statistics Analysis According Ghozali the variables used in this study are described by using descriptive statistics to determine the mean, minimum, maximum, and standard deviation [7]. Mean is the average value of each research variable. Minimum is the lowest value of each research variable. Maximum is the highest value of each research variable. Standard deviation is used to determine the amount of variation of the data used against the average value. Classic assumption test The classical assumption test is used to test the accuracy of the model. The classical assumption test that will be used is:

\section{A. Normality Test}

This test aims to test whether the regression model, the independent variable and the dependent variable are normally distributed. Normality of data can be seen by using the normal test Kolmogorov-Smirnov. The decision criterion is if sig $>$ 0,05 then the data is normally distributed and if sig $<0,05$ then data is not normally distributed [7]. 


\section{B. Heteroscedasticity Test}

The test aims to test whether in the regression model there is a variance inequality of the residual one observation to another observation. Significant correlation value> 0,05 $(\alpha=$ $5 \%$ ) hence can be concluded not happened heteroscedasticities [7].

\section{Autocorrelation Test}

This test aims to test whether linear regression model there is correlation between fault error in period $t$ with error in period $\mathrm{t}-1$ (previous year). A good regression model is a regression independent of autocorrelation or no autocorrelation. If $\mathrm{d}$ is smaller than $\mathrm{dL}$ or greater than $(4-\mathrm{dL})$ then the null hypothesis is rejected, meaning there is autocorrelation. If $\mathrm{d}$ lies between $\mathrm{dU}$ and (4-dU), then the null hypothesis is accepted, meaning there is no autocorrelation. If $\mathrm{d}$ lies between $\mathrm{dL}$ and $\mathrm{dU}$ or between (4-dU) and (4-dL), then it does not produce a definite conclusion [7].

1) Hypothesis testing: Hypothesis test is done to know the influence between the dependent variable $(\mathrm{X})$ with independent (Y). Data analysis used in this research is time series. The model of regression equation in this research are:

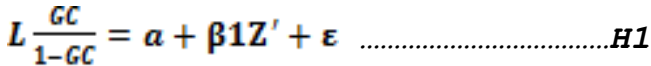

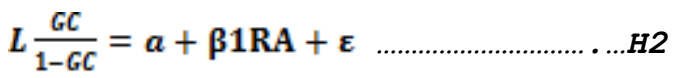

Information:

$\mathrm{GC}=$ probability of getting going concern audit opinion

$\alpha=$ constant

$\mathrm{Z}^{\prime}$ = Altman's predicted bankruptcy model

$\mathrm{AR}=$ auditor's reputation

$\varepsilon=$ error term

Hypothesis testing in this study using static test $t$. The statistical test $\mathrm{t}$ is used to test the first hypothesis and the second hypothesis. According to Ghozali, the statistical test $t$ aims to know the significance of roles partially between independent variables to the dependent variable by assuming that the other independent is considered constant [6]. If the probability significance value $<0.05$ means, there is a significant influence between independent variables partially with the dependent variable [6]. The first and second hypotheses are supported if the regression coefficient is positive and the significance value $t$ is less than 5\%, whereas if the regression coefficient is negative or the value of $t$ is more than $5 \%$ then the hypothesis is not supported.

\section{DISCUSSION}

This research uses the population of manufacturing sector companies listed in Indonesia Stock Exchange (BEI) period 2013-2015. This study uses only 80 sample manufacturing companies from 134 manufacturing companies in the period 2013-2015. In accordance with the required sample criteria. The following explanation of the sample used in the study can be seen in Table I.
TABLE I. TOTAL SAMPLE PERIOD

\begin{tabular}{|l|l|}
\hline \multicolumn{1}{|c|}{ Company Indication } & Total \\
\hline $\begin{array}{l}\text { Companies manufacturing companies listed on the Indonesia } \\
\text { Stock Exchange period 2013-2015 }\end{array}$ & 134 \\
\hline $\begin{array}{l}\text { Companies that use foreign currency in reporting during the } \\
\text { study period 2013-2015 }\end{array}$ & 30 \\
\hline $\begin{array}{l}\text { Companies that do not issue complete financial statements } \\
\text { during the study period 2013-2015 }\end{array}$ & 24 \\
\hline The selected companies become the sample per year & 80 \\
\hline Total sample period 2013-2015 & 240 \\
\hline
\end{tabular}

Source: Data is processed based on own analysis

Descriptive statistical analysis is used to provide an overview or description of data viewed from values including mean, minimum, maximum, and standard deviations from going concern audit opinion (GC), bankruptcy prediction model ( $\mathrm{Z}$ 'Score), and reputation auditor (RA). Descriptive statistics of the sample used in this study can be seen in table 2 .

TABLE II. DESCRIPTIVE STATISTICS OF THE SAMPLE USED

\begin{tabular}{|c|l|l|l|l|l|}
\hline & \multicolumn{1}{|c|}{$\mathbf{N}$} & \multicolumn{1}{|c|}{ Min } & \multicolumn{1}{|c|}{ Max } & Mean & Std. Deviation \\
\hline $\boldsymbol{G C}$ & 240 & 0 & 1 & .12 & .331 \\
\hline $\boldsymbol{R A}$ & 240 & 0 & 1 & .36 & .482 \\
\hline $\boldsymbol{Z}$ & 240 & .49 & 7.11 & 3.1671 & 1.25759 \\
\hline $\begin{array}{c}\text { Valid } \boldsymbol{N} \\
\text { (list wise }\end{array}$ & 240 & & & & \\
\hline
\end{tabular}

Based on table 2 above, it can be seen that the amount of data used in this study is 240 sample data. This study examines the independent variables of the predicted model of bankruptcy measured by $\mathrm{Z}$ 'score and auditor reputation measured by the classification of Public Accounting Firm (KAP) into big four and non-big four, the dependent variable is going concern audit opinion as measured by the presentation of audit opinion by Public

Based on the descriptive statistics of table 2, it is known that the minimum going concern value of 240 samples is 0 , the maximum value is 1 , the standard deviation value is 0.33 , with an average of 0.12 . It shows that an average of 0.12 indicates that few companies accept going concern audit opinion based on assumptions issued by Public.

\section{A. Accounting Firm (KAP)}

The standard deviation for the auditor's reputation is 0.482 , with a minimum value of 0 , and the maximum value is 1 . For an average of 0.36 indicates that only a few companies use the services of Public Accounting Firm (KAP) which belong to the big four and the rest using the services of Public Accounting Firm (KAP) are classified into non big four.

The predicted bankruptcy model measured by Z 'Score has an average value of 3.1671 , a standard deviation of 1.25759 , a minimum value of 0.49 and a maximum value of 7.11 . The average score of Z 'Score which has a value of 3.1671 and greater than 2.99 indicates that the average sample company has a healthy financial condition and is considered able to survive in the business market. Few companies have the potential to go bankrupt and be in the gray area. 


\section{B. Classical Assumption Tests}

The research data must first be approved by Classic before a simple linear regression analysis is offered to know whether or not influence between independent variable to dependent variable. The classical assumption test that needs to be done is adjusted to the type of testing required in the study.

\section{Normality Test}

Normality test aims to test whether the regression model, independent variables and dependent variable normal distribution. The normality of the data can be seen by using the output result from the normal Kolmogorov-Smirnov test. Criteria of decision making normality test is if the value of sig $>$ 0,05 hence normal distributed data and if value of $\operatorname{sig}<0,05$ hence data not normally distributed [7].

Based on the results of normality test data obtained from the output of SPSS in table 4.3 shows that the value of Kolmogrov-Smirnov amounted to 1.089 and significance data value is above 0.05 that is with the value of 0.189 , so it can be concluded that the residual data is normally distributed.

\section{Heteroscedasticity Test}

Heteroscedasticity test aims to illustrate the interference factors that do not have the same variant for the overall observation of the independent variables. This study uses Glejser test to meguji whether or not heteroscedasticities on data used by researchers. The Glejser test is performed by regressing the absolute value of the residual data against the independent variable. If the significant value of correlation is greater than $0.05(\alpha=5 \%)$ then it can be concluded there is no heteroscedasticities, so otherwise [7].

Shows that the independent variable in the form of going concern has a significance value of 0.129 . The value indicates that there is no heteroscedasticity because the significant value is greater than 0.05 . As for the dependent variable in the form of auditor's reputation has a significance value of 0.442 . The value indicates that there is no heteroscedasticity because the significant value is greater than 0.05 .

\section{E. Autocorrelation Test}

A good regression model is a regression independent of autocorrelation or no autocorrelation. If $\mathrm{d}$ is smaller than $\mathrm{dL}$ or greater than (4-dL) then the zero hypothesis is rejected, meaning there is autocorrelation. If $\mathrm{d}$ lies between $\mathrm{dU}$ and (4$\mathrm{dU})$, then the null hypothesis is accepted, meaning there is no autocorrelation. If $\mathrm{d}$ lies between $\mathrm{dL}$ and $\mathrm{dU}$ or between (4-dU) and (4-dL), then it does not produce a definite conclusion [7].

Based on the result of output it is found that DW value equal to 1,865 , the value will be compared with significance table value $5 \%$. The number of samples is 240 (n) and the number of independent variables $2(K=2)=2.72$, the value of $\mathrm{du}$ is 1.688 .

DW value of 1.865 is greater than the upper limit (du) of 1.688 and less than (4-du) 4-1,688 = 2,312 means it can be concluded that there is no autocorrelation in the data processed by researchers.

\section{F. Hypothesis Testing}

Hypothesis testing in this research is done by using simple linear regression analysis and doing partial test (t test statistic) processed by using SPSS vers.17. The results of the statistical test will show how far the influence of one independent variable individually in explaining the variation of the dependent variable.

1) Hypothesis 1: The first hypothesis proposed in this study states that going concern audit opinion has a positive effect on bankruptcy prediction model. This hypothesis can be supported if the significance value shows a value less than 0.05 and can not be supported if otherwise. The result of $t-$ significance test of the first equation model in this research can be seen in table 3 .

TABLE III. The Result OF T-SignifiCANCE TEST OF THE FiRST EQUATION MODEL

\begin{tabular}{|c|l|l|l|l|}
\hline Variable & \multicolumn{1}{|c|}{ B } & $\begin{array}{c}\text { Standard } \\
\text { Error }\end{array}$ & \multicolumn{1}{|c|}{ t-count } & Sig. \\
\hline Constanta & 3.354 & .080 & 41.996 & .000 \\
\hline $\boldsymbol{G C}$ & - & .226 & -6.617 & .000 \\
\hline $\boldsymbol{R}$-Square & 1.496 & & .155 & \\
\hline Adjusted R-Square & & & .152 & \\
\hline
\end{tabular}

source: Data SPSS 17.0

Based on the table 3 can be seen that the value of going concern significance of 0.000 is smaller than $0.05(0,000$ $<0.05$ ) and the value of $t-6,617$ (negative), so the hypothesis that the opinion of going concerns positively affect the bankruptcy prediction model can be accepted or supported. The regression equation can be written as follows:

$$
L G C /(1-G C)=3,354-1,496 Z^{\wedge}{ }^{\prime}
$$

The above equation shows that there is significant influence between the independent variable to the dependent variable. The definition of the regression equation is a going concern audit opinion of 3.354 will decrease and negative by -1.496 if the variable predictions model bankruptcies fell 1 unit. The coefficient of determination (Adjusted R2) of 0.152, it is stated that only $15.2 \%$ dependent variable is going concern opinion can be explained by independent variable that is bankruptcy prediction model. While the rest $(100 \%-15.2 \%=84.8 \%)$ other causes outside the model. Influence of Going Concern Audit Opinion to Prediction Model of Bankruptcy.

Based on the results of statistical tests, H1 showed that a significant influence between going concern opinion on the predicted model of bankruptcy. This suggests that the first hypothesis $(\mathrm{H} 1)$ is supported. These results indicate that the prediction model of bankruptcy that use the formula $\mathrm{Z}$ 'Score is considered able to predict the potential bankruptcy of a company through going concern audit opinion issued by Public Accounting Firm (KAP). The results of this study have the same conclusion with research Rudyawan and Badera which states that there is a significant positive relationship between the predicted model of bankruptcy against the release of going concern audit opinion [2] 
2) Hypothesis 2: The second hypothesis proposed in this study states that going concern audit opinion positively affects the auditor's reputation. This hypothesis can be supported if the significance value shows a value less than 0.05 and can not be supported otherwise. The result of t-significance test of second equation model in this research can be seen in table 4 .

TABLE IV. ThE RESUlt OF T-SignifiCANCE TEST OF SECOND EQUATION MODEL

\begin{tabular}{|l|l|l|l|l|}
\hline \multicolumn{1}{|c|}{ Variable } & \multicolumn{1}{|c|}{ B } & \multicolumn{1}{c|}{$\begin{array}{c}\text { Standard } \\
\text { Error }\end{array}$} & \multicolumn{1}{c|}{ t-count } & Sig. \\
\hline Konstanta & 3.071 & .101 & 30.297 & .000 \\
\hline RA & .266 & .168 & 1.579 & .116 \\
\hline R-Square & & & .010 & \\
\hline Adjusted R-Square & & & .006 & \\
\hline
\end{tabular}

Source: Data SPSS 17.0

Based on the above table it can be seen that the auditor's reputation significance of 0.116 is greater than $0.05(0.116>$ 0.05 ) and $t$ value 1.579 (positive), so the hypothesis that the going concern audit opinion positively affects the auditor's reputation is unacceptable or not supported. The regression equation can be written as follows:

$$
\mathrm{L} \mathrm{GC} /(1-\mathrm{GC})=3.071+0.266 \mathrm{RA}
$$

The above equation shows no significant influence between independent variable to dependent variable. The definition of the regression equation is a going concern audit opinion of 3,071 will be increased and positive by 0.266 if the auditor's reputation variable rises 1 unit. The coefficient of determination (Adjusted R2) is 0.006 , it states that only $0.6 \%$ of the dependent variable is going concern audit opinion can be explained by independent variable that is auditor reputation. While the rest $(100 \%-0.6 \%=99.4 \%)$ other causes outside the model.

The Effect of Going Concern Audit Opinion on the Auditor's Reputation

Based on the result of statistical test, $\mathrm{H} 2$ shows that there is no significant influence between going concern opinion toward auditor reputation. This suggests that the second hypothesis (H2) is not supported. The result stated that Public Accountant
Office (KAP) affiliated with Public Accountant Office (KAP) big four and non-big four both provide good audit quality and be independent in issuing going concern audit opinion. Public Accounting Firm (KAP) in conducting audits of financial statements should be based on the applicable Public Accountant Standards (SPAP) and Financial Accounting Standards (SAK). The results of this study support research conducted by Rudyawan and Badera [2] and support research conducted regarding the influence of the auditor's reputation on the presentation of corporate audit reports.

\section{CONCLUSION}

This research is conducted to analyze whether there is influence on issuing going concern audit opinion by Public Accounting Firm (KAP) based on prediction model bankruptcy and reputation auditor at manufacturing company in Indonesia. This research performs sample test in the period of study year 2013-2015 by testing the data through SPSS vers.17. The results showed that the predicted model of bankruptcy used to influence the acceptance of going concern audit opinion on the related companies. The auditor's reputation variable has no effect on the acceptance of going concern audit opinion.

\section{REFERENCES}

[1] E. Altman, Corporate Financial Distress and Bankruptcy: AComplete Guide to Predicting and Avoiding Distress and Profiting from Bankruptcy. New York, NY: Wiley, 1993.

[2] A.P. Rudyawan and I.D.N. Badera, Opini audit going concern: Kajian berdasarkan model prediksi kebangkrutan, pertumbuhan perusahaan, leverage, dan reputasi auditor. Jurnal Ilmiah Akuntansi dan Bisnis, 2009.

[3] I. Subekti, Asosiasi antara praktik perataan laba dan reaksi pasar modal di Indonesia. Simposium Nasional Akuntansi VIII, 2005, pp. 223-236.

[4] M. Fanny and S. Saputra, "Opini audit going concern: Kajian berdasarkan model prediksi kebangkrutan, pertumbuhan perusahaan, dan reputasi kantor akuntan publik (studi pada emiten bursa efek Jakarta)," Simposium Nasional Akuntansi, vol. 8, pp. 966-978, 2005.

[5] S. Munawir, Akuntansi Keuangan dan Manajemen. Edisi Revisi. Penerbit BPFE. Yogyakarta, 2002.

[6] D. Siagian and Sugiarto, Metode Statistik untuk Bisnis dan Ekonomi, PT. Gramedia Pusaka Utama, Jakarta, 2002.

[7] I. Ghozali, Aplikasi Analisis Multivariate dengan Program SPSS. Semarang: Badan Penerbit Universitas Diponegoro, 2006. 